\title{
Objetos rituais no candomblé da Bahia
}

\author{
Ana Maria Amaral
}

andomblé é um nome genérico que designa um conjunto de crenças religiosas cujas origens estão na África. Chegou ao Brasil através dos africanos trazidos como escravos no período colonial. O Candomblé do Brasil divide-se em 3 grandes naçōes, Angola, Jeje, Ketu, e subdivide-se em vários outros cultos mistos. É no estado da Bahia, notadamente na cidade de Salvador, que o Candomblé se apresenta com grande esplendor ${ }^{1}$. $\mathrm{O}$ termo Candomblé designa também um espaço - o terreiro - onde são realizados os rituais e onde estão os santuários das divindades. Em Salvador os principais terreiros são: Axé Apô Afonjá, Gantois, Olga de Alaketu, Casa Oxumaré, Oxum Apará.

É uma religião monoteísta. Olorum é o criador do Universo, mas, depois que criou o mundo, Olorum não interferiu mais nele. Oxalá, seu filho, recebeu do pai a incumbência de gerar os homens. Os seus auxiliares, ou ministros, são os Orixás.
Os Orixás são forças da natureza. Eles habitam determinados elementos: terra, água, vento, conchas, árvores, pedaços de madeira ou de ferro, frutas, pedras, principalmente pedras. As pedras são as suas moradas favoritas. Os Orixás habitam na natureza, mas manifestamse através do ser humano. É uma religião que intensifica e incentiva a relação homem/natureza. O Candomblé busca assim o equilíbrio entre os seres materiais, originários do interior da terra, e os seres não-materiais do céu, procurando sempre conectar esses dois planos. A conexão entre os humanos e as divindades acontece durante os rituais.

Os Orixás não têm representação antropomórfica ou zoomórfica. Eles são representados por suas moradas; em segunda instância, são também representados por objetos-símbolos, identificados como ferramentas dos Orixás. Essas ferramentas ou objetos servem para ajudar os crentes a visualizar e perceber melhor os seus deuses. São objetos artesanais construídos de

Ana Maria Amaral é professora titular do Departamento de Artes Cênicas da ECA-USP.

1 Fundada em 1549 por Thomé de Souza, Salvador foi, até 1763, capital do Brasil colonial. A cidade de Salvador apresenta a maior concentração de descendentes afros das Américas. Atualmente a população negra de Salvador atinge $80 \%$ de seus habitantes. Os africanos foram trazidos ao Brasil, durante o período colonial, para trabalharem como escravos na lavoura. Eram originários da região compreendida entre Camarões e a Nigéria, e da região Centro-Sul da África, onde havia uma civilização conhecida como Banto. 
ferro, latão, cobre, barro, tecido, palha, madeira, búzios, contas, ou são os próprios elementos naturais, usados em estado puro, como pedras, vegetais, água, terra. Eles são ritualmente depositados nos pejis, espécie de santuário que cada Orixá tem nos terreiros, onde são colocadas também tigelas com as comidas preferidas de cada Orixá ${ }^{2}$. Outras manifestações como vento, fogo, raios e trovões, estão também presentes nos rituais através de sons, ritmo, movimento, cor.

$\mathrm{Na}$ África existem mais de 600 Orixás. No Brasil tem-se conhecimento de pelo menos 50. Destacamos alguns:

Oxalá é o pai de todos. Recebeu de Olorum, o Supremo, a incumbência de gerar os homens. Sua cor é o branco e seu símbolo é um cetro de prata ou metal ${ }^{3}$.

Xangô, senhor da justiça, é representado por raios, trovões e tempestades. Sua ferramenta é um machado com asas.

Oxóssi é o deus da caça. Suas ferramentas são armaduras, arcos e flechas, espingardas. Cultiva a solidão e habita as florestas.

Ogum é o Orixá das estradas. Suas ferramentas são instrumentos de lavoura, enxada, pá, foice, picareta.

Oxumaré é o Orixá do arco-íris. É representado por uma serpente. Seu símbolo é um tridente.

Iemanjá, mãe das águas, é a rainha do mar. As festas em sua homenagem são famosas em quase todo litoral do Brasil, quando lhe são entregues oferendas, colocadas no mar: flores, espelhos, perfumes, rendas.
Nanã é a mãe de todos os Orixás

Oxum mora na água doce, em regatos e fontes.

Iansã é a deusa do vento, suas cores são o rosa, o verde, o marrom. Suas danças despertam vibrações fortes de alegria, e em seu dia de festas as vestimentas são muito coloridas e o é ambiente decorado com flores e folhagens exuberantes.

Omolu é o deus das doenças contagiosas. Em sua festa, o chão é coberto por pipocas que os crentes esfregam nos corpos para se prevenirem de doenças ${ }^{4}$.

O Candomblé se estabelece e vive dentro de um espaço próprio, o terreiro. Nos terreiros existem várias construções entre as quais se destaca o grande galpão destinado às cerimônias; os pejis; as casas para os rituais de iniciação; salas de consulta; o grande refeitório; e as casasdormitórios onde as famílias dos adeptos mais ligados ao culto moram em comunidade. No terreiro do Axé Apô Afongé existe também uma escola primária para as crianças que moram no terreiro e uma escola profissionalizante para adolescentes da comunidade externa, além de um pequeno museu.

O terreiro é regido pela mãe-de-santo ou por um pai-de-santo (sempre houve uma preponderância do poder feminino). $\mathrm{O}$ poder da mãe ou pai-de-santo é absoluto. Acima deles só os Orixás. A chefia é hereditária, mas ainda que hereditários, os candidatos aos cargos devem seguir um longo processo de iniciação. A mãe-desanto, além de cuidar da vida espiritual de sua comunidade, cuida dos problemas administrativos,

2 Pejís são pequenas construções que variam de tamanho, de acordo com o tamanho do terreiro.

3 Suas festas são as mais suntuosas. Para delas participarem, crentes e público devem vestir roupas brancas. $\mathrm{Na}$ procissão inicial, sob as árvores do terreiro, à luz de velas, uma multidão de vultos brancos caminha entoando cânticos, conferindo ao ambiente uma atmosfera mágica.

4 Nesse universo destaca-se Exu. Nem sempre é considerado um Orixá, mas um intermediário entre os homens e os Orixás, funciona como uma espécie de mensageiro, o que o coloca numa posição dúbia. Exu preside a fecundidade, sendo as danças em sua homenagem representações do ato sexual. Por não ser propriamente um Orixá, tem representação antropomórfica, nu, com chifres e um grande falo. Sua ferramenta é um bastão com pontas em lança. Habita as encruzilhadas. 
financeiros e civis. Está sempre muito atenta às regras litúrgicas que devem ser seguidas sempre, de acordo com a tradição ${ }^{5}$. Ela rege não só a vida espiritual dos adeptos mais próximos, como é também guia espiritual de pessoas estranhas à própria comunidade ${ }^{6}$. Sua influência estende-se além da vida religiosa, atingindo o comportamento individual e social de todos os seus membros. Mas a sua preocupação maior é no trato com os deuses.

Os terreiros de Salvador são freqüentados por grupos sociais heterogêneos, pertencentes a diferentes classes sociais, com grandes diferenças de educação e profissão. Abrangem das classes mais humildes (operários e desempregados) a professores universitários, artistas e escritores ilustres, alguns de renome internacional. Observa-se nos terreiros a ausência de preconceitos, normalmente vigentes no dia a dia da sociedade brasileira.

Os rituais seguem um ciclo anual. As festas em homenagem aos Orixás começam no nascer do sol, em cerimonias fechadas, das quais participam apenas os crentes mais ligados à seita. Os preparativos para a festa, que acontecem no período da tarde, esses são abertos a todos. As danças no grande galpão - o ritual propriamente - iniciam-se às 8 horas da noite e estendem-se até mais de meia noite. A festa começa com o som dos atabaques. $\mathrm{Na}$ cabeceira do salão estão dispostos os lugares das autoridades, de acordo com a hierarquia. Bancos simples para a comunidade, assistentes, visitantes, ladeiam o grande círculo7.

Começa a dança circular. De olhos fechados, os iniciados lembram, com movimentos, passagens da vida dos Orixás, principalmente os que na ocasião são homenageados. Cada divindade tem sua dança peculiar: mão para cima, mãos para o chão, joelhos dobrados, braços em forma de espingarda, pulando num pé só, etc. Algumas coreografias são repetitivas e monótonas, outras são mais vivas, com saltos e súbitas reviravoltas, outras ainda seguem lentamente, com passos pesados, senhoriais. O momento da dança é o momento do transe, é quando "baixam os santos", quando os deuses se apossam dos crentes que então se transformam em "cavalos” dos Orixás. Possuídos, os crentes passam a ser instrumentos ${ }^{8}$. Através do corpo orgânico do homem faz-se a ligação entre o natural, visível e o sobrenatural, invisível, e se estabelece um diálogo entre deuses, homens e natureza9.

Depois que os "santos baixaram", os crentes se recolhem, um a um, para uma sala contígua onde são preparados, aparamentados com luxuosas vestimentas, próprias de cada Orixá. A batida dos tambores continua, e quando os crentes retornam ao círculo, em grande gala, o momento é de grande comoção. Esplendorosamente vestidos, trazem agora nas mãos os objetos, objetos-símbolos, ou seja as suas respectivas "ferramentas". A orquestra toca o ritmo de cada Orixá, e um por vez, os santos são saudados.

5 Além dos atos de culto existem atitudes a serem seguidas na rotina quotidiana. Como proceder, por exemplo, ao chegar no terreiro? Primeiro é preciso descansar o pó da estrada. Depois tomar banho e vestir-se adequadamente. Só então cumprimentar Xangô, depois a Mãe, ou Pai, de Santo, e as autoridades presentes. Depois se saúdam os mais velhos.

6 Comunidade aqui se refere não apenas aos que moram no terreiro, como aos que o freqüentam regularmente, tanto os originários da própria cidade como pessoas distantes de outras cidades ou estados.

7 Os visitantes são acolhidos com simpatia, oferecem-lhes lugares e no momento da refeição são servidos com prioridade.

8 O que é transe? Transe é um silencio interior, é a neutralidade do ser que se torna disponível, facilitando a passagem das vibraçõos do universo ao mesmo tempo em que se impregna delas.

9 "Baixar o santo" é o momento de transe, quando o crente incorpora a divindade. 
As pessoas presentes dispostas à volta do círculo levantam-se e respeitosamente conservam-se de pé até que os cânticos terminem. Depois é a vez dos santos saudarem os presentes.

Sabe-se que é próprio dos mitos, manifestados nos rituais, expressar pensamentos e idéias através dos símbolos. E como bonequeira, atraída pelos objetos rituais, constatei que os objetos que os crentes portam não são animados, nem dramaticamente manipulados. Servem apenas para reforçar as características de seus Orixás. O que é realmente animado ou manipulado são os corpos dos crentes que, depois de terem passado pelo processo de iniciação, recebem e manifestam o santo.

No Candomblé, a construção dos objetos rituais é feita por artistas e artesãos. Depois de prontos, antes do uso, passam por um processo de "limpeza": uma infusão de água e folhas, sendo deixados também ao relento por um tempo. Também a construção dos instrumentos musicais é um ritual que vai desde a escolha da madeira e do couro até a afinação, seguida da tarefa de "alimentar" o instrumento, isto é, colocar-lhe uma alma. Recebem nomes secretos e só quem os fez e usa, conhece. Assim de simples coisa passam a ser objetos de culto. Passam a ser morada dos deuses.

Mas o objeto mais importante desses rituais é o próprio corpo do homem que, em transe, se transforma em instrumento, em "homem-cavalo". Nesse momento, pode-se dizer que o Orixá é o sujeito e o ser humano, quando possuído, é seu objeto.

Teatro ou ritual? Vejo no "homem-cavalo" uma relação com o ator, que também incorpora em seu corpo o personagem. $\mathrm{O}$ corpo do ator aí é um reflexo. E o bonequeiro que, através de seu corpo e de suas mãos, incorpora o personagem-boneco, faz desse objeto o reflexo de um reflexo.
Certamente há uma diferença entre personagem de teatro, personagens-bonecos e os objetos rituais. Mas, essa diferença, qual é? Segundo Joan Baixas, houve um tempo em que: "o pensamento mitológico era a única forma do raciocínio humano e todo o saber habitava os mitos, as energias básicas que estruturavam o viver dos homens se materializavam em bonecos animados (...). Títeres, fetiches e máscaras eram formas corpóreas do conhecimento (...) viviam e incorporavam os mitos. Mais que personagem teatrais, são mistérios (...). Posteriormente, na Europa, os bonecos perderam essas características sagradas e assumiram arquétipos psicológicos, até que, no século $\mathrm{XX}$, as vanguardas os redescobrem" (Baixas, p. 40). A diferença entre personagem de teatro, bonecos e objetos rituais talvez esteja no contexto em que se apresentam, e não necessariamente em períodos cronológicos da historia do homem. Na Bahia os mitos ainda vivem e atuam nos rituais do Candomblé, ainda participam da vida quotidiana de uma grande camada da sociedade.

Os rituais de Candomblé são verdadeiros espetáculos de dança com coreografias, figurinos e um código específico de cores, elementos esses que variam de acordo como o Orixá homenageado. $\mathrm{O}$ resultado é o de um grande espetáculo que se repete todas as noites, diferentemente $^{10}$. Poético e religioso. Sob o ponto de vista ortodoxo não é teatro, não é drama. Tão pouco é entretenimento. Não se dirige à platéia, mas a platéia dele participa ativamente (freqüentemente ocorrem transes entre os assistentes).

Máscaras - no sentido de ocultar e revelar - são as vestimentas, os figurinos, o ritmo, os movimentos, a cenografia do ambiente. O sagrado e o profano aí se conjugam. Como na África, o Candomblé afro-brasileiro ao mesmo tempo em que apresenta o sagrado, é uma encenação artística.

10 As festas seguem um calendário cíclico. Há um período do ano em que as festas ocorrem pelo menos uma vez por semana. 
O humano e divino se misturam. O candomblé é vida religiosa e social. Em Salvador, o sagrado está intimamente ligado ao cotidiano. Os Orixás estão nos terreiros como estão na natureza, estão na cidade, nas ruas, na intimidade das casas, no ar, nas técnicas artesanais, nas vestimentas, na maneira de preparar a comida para as ceias entre deuses e homens. Através do Candomblé são colocados e seguidos os códigos éticos e morais da sociedade. É também através dele que a cultura africana se preserva no Brasil, melhor dito, em Salvador e na Bahia, com uma identidade própria, despertando e afirmando a consciência afro-brasileira.

Todos os povos têm diferentes experiências com o sagrado. E hoje, no limiar de um novo século, abre-se a perspectiva de um futuro em que a diversidade parece ser a tônica. Talvez seja o alvorecer de uma era melhor, em que homens de diferentes raças e credos um dia venham a se respeitar mais, respeitando as diferentes experiências sobre o sagrado que cada grupo ou povo possui, pois diferentes são as formas de conhecer e expressar a sabedoria do mundo.

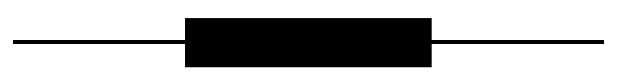

\section{Referências bibliográficas}

ASSOCIAÇÃO CULTURAL ILÊ AIYÊ. Cadernos de Educação. ns. 2 e 4. Salvador, s.d.

BAIXAS, J. “A peculiar itinerary”. In: Malic. n. 3. Barcelona.

CARNEIRO, E. Os Candomblés da Bahia. Rio Janeiro, Ediouro, s.d.

LODY, R. Candomblé, religiāo e resistência cultural. São Paulo, Ed. Ática, 1987.

. Um documento do Candomblé na cidade do Salvador. Salvador, MinC/Funarte, 1985.

MAIA, V. $A B C$ do Candomblé. São Paulo, GRD, 1985.

Revista Planeta: Os Orixás. Número especial.

SCHECHNER, R. Between theater and anthropology. Philadelphia, University of Pennsylvania Press, 1985.

TURNER, V. The anthropology of performance. Nova York, PAJ, 1988.

VERGER, P.F. Lendas africanas dos Orixás. Salvador, Corrupio Ed., 1992.

. Orixás. Salvador, Corrupio Ed., 1997. 